\title{
KARCINOMI KOŽE UZROKOVANI SOLARNIM ZRAČENJEM KAO PROFESIONALNA BOLEST
}

UDK 616.5-006:613.645

PRIMLJENO: 23.1.2018.

PRIHVAĆENO: 12.6 .2018$.

\begin{abstract}
SAŽETAK: Cilj ovog preglednog rada je ukazati na opasnost koja prijeti radnicima koji zbog prirode svojeg zanimanja većinu radnog vremena provode na otvorenom i tako su izloženi sunčevom zračenju koje povećava njihov rizik za obolijevanje od karcinoma kože.

Izlaganje sunčevom UV zračenju tijekom rada na otvorenom 4-5 puta povećava primljenu prosječnu godišnju dozu UV zračenja u odnosu na osobe koje ne rade na suncu, što kod radnika koji rade na otvorenom značajno povećava rizik pojave aktiničke keratoze, bazeocelularnog i planocelularnog karcinoma kože. Smatra se da se rizik za pojavu ovih poremećaja udvostručuje ako je procijenjena ukupna cjeloživotna doza UV zračenja za osobe koje ne rade izloženi suncu (130 SED godišnje) premašena za $40 \%$. U zemljama EU-a, uključujući i Hrvatsku, u tijeku je uvođenje osobne dozimetrije UV zračenja za radnike koji rade na otvorenom.

Kako bi se spriječili tumori kože uzrokovani profesionalnom UV izloženosti, obvezno je provođenje preventivnih mjera kod radnika na otvorenom. Minimalnim standardima prevencije na razini EU-a smatraju se primjene mjera osobne zaštite (naočale, pokrivala za glavu, odjeća, kreme sa zaštitnim faktorom) i programa edukacije o zdravlju i sigurnosti na radu implementiranih u kurikule srednjih strukovnih škola i pružane radnicima na rizičnim radnim mjestima.

Karcinomi kože ili multipla aktinična keratoza mogu biti prepoznati kao profesionalne bolesti ako je: 1) histološki potvrđena dijagnoza planocelularnog ili bazeocelularnog karcinoma kože ili multiple aktiničke keratoze (minimalno 6 promjena); 2) promjene su izražene na profesionalno izloženim dijelovima kože; 3) povijest bolesti otkriva dostatnu profesionalnu izloženost UV zračenju.
\end{abstract}

Ključne riječi: ultraljubičasto zračenje, karcinogeni, rad na otvorenom, osobna dozimetrija, prevencija, osobna zaštitna sredstva

\section{UVOD}

Prema Zakonu o listi profesionalnih bolesti (1998.) i Zakonu o izmjenama i dopunama Zakona o listi profesionalnih bolesti (2007.), članku 2., profesionalnom bolešću „smatra se bolest za koju se dokaže da je posljedica djelovanja

*Krunoslav Mikolašević, dr. med., (kruno.mikolasevic@gmail. com), Dom zdravlja Đakovo, Petra Preradovića 2, 31400 Đakovo, prim. dr. sc. Jelena Macan, dr.med., (jmacan@imi.hr), Institut za medicinska istraživanja i medicinu rada, Ksaverska cesta 2, 10000 Zagreb. štetnosti u procesu rada i/ili radnom okolišu, odnosno bolest za koju je poznato da može biti posljedica djelovanja štetnosti koje su u svezi s procesom rada i/ili radnim okolišem, a intenzitet štetnosti i duljina trajanja izloženosti toj štetnosti je na razini za koju je poznato da uzrokuje oštećenje zdravlja". Profesionalni karcinomi su bolesti koje se pojavljuju kod ljudi koji tijekom obavljanja svojeg zanimanja dolaze u dodir s različitim karcinogenima, a klinički niti biološki se ne razlikuju od karcinoma drugog podrijetla. Pod pojmom profesionalni karcinom u Republici 
Hrvatskoj podrazumijevaju se svi karcinomi koji se, u skladu sa Zakonom o listi profesionalnih bolesti i njegovim izmjenama i dopunama, mogu priznati profesionalnim bolestima, odnosno one karcinome kod kojih je neosporan uzrok karcinomu karcinogena tvar prisutna kao štetnost na radnom mjestu. Profesionalni karcinogeni dijele se u tri osnovne skupine prema štetnosti koja uzrokuje određeni karcinom: 1) kemijski karcinogeni (na primjer benzen, vinil klorid); 2) fizikalni karcinogeni od kojih su najpoznatiji ultraljubičasto i ionizirajuće zračenje i 3) biološki karcinogeni među kojima karcinome najčešće izazivaju virusi hepatitisa B i C (Zavalić, 2006.).

Prema Zakonu o listi profesionalnih bolesti i njegovim izmjenama i dopunama, karcinomi kože uzrokovani ultraljubičastim (eng. ultraviolet, UV) zračenjem mogu se svrstati pod poglavlje „Bolesti uzrokovane fizikalnim štetnostima i naprezanjima“, točku 39. „Bolesti uzrokovane neionizirajućim zračenjima", ali za sada u Republici Hrvatskoj nije registriran niti jedan slučaj profesionalnog karcinoma kože uzrokovanog UV zračenjem. Pravilnik o poslovima s posebnim uvjetima rada (1984.) te u njemu navedeni Popis poslova s posebnim uvjetima rada ne spominje u poglavlju koje se odnosi na izloženost neionizirajućem zračenju utjecaj sunčevog UV zračenja kao štetnosti na radnom mjestu, već samo neionizirajuća zračenja iz umjetnih izvora.

Cilj ovog preglednog rada je podizanje svijesti o štetnosti sunčevog zračenja kao profesionalnog rizičnog čimbenika s potrebom razmatranja pojave karcinoma kože kao profesionalne bolesti, uz upoznavanje s novim mogućnostima dozimetrije solarnog zračenja u uvjetima profesionalne izloženosti, te s preporučenim preventivnim mjerama za sprečavanje štetnih zdravstvenih učinaka solarnog zračenja u izloženih radnika.

\section{SOLARNO ZRAČENJE KAO KARCINOGEN}

\section{Fizikalne karakteristike i zdravstveni učinci ultraljubičastog zračenja}

UV zračenje obuhvaća dio spektra elektromagnetskog zračenja s valnim duljinama manjim od onih koje ima vidljiva svjetlost, ali većim od onih koje imaju meke $X$-zrake, tj. dio spektra $s$ valnim duljinama u rasponu od 400 do $10 \mathrm{~nm}$. lako djeca i mlađe osobe u nekim stanjima, kao i osobe s afakijom, tj. nedostatkom očne leće, mogu vidjeti UV zračenje valnih duljina od oko 310 nm, UV svjetlo je nevidljivo većini ljudi (Lynch i Livingston, 2001.). UV zračenje se obično dijeli na UVA ili dugovalno (400-315 nm), UVB ili srednjovalno (315-280) i UVC ili kratkovalno (<280 nm; antimikrobno). Sunce zrači UV zračenje u sva tri dijela. Zemljin ozonski omotač, ako je cjelovit, zaustavlja $97 \%$ - $99 \%$ sunčevog UV zračenja, te do površine Zemlje stigne tek mali dio u dijelu UVA i UVB, s većom zastupljenosti UVA zračenja. Organizmi koji žive na suhom bili bi teško oštećeni sunčevim UV zračenjem kada većinu zračenja ne bi upijala zemljina atmosfera, osobito ozonski omotač (NASA).

Za razliku od svjetlosnih i toplinskih (infracrvenih) zraka, koje zamjećujemo posebnim osjetilima našeg tijela, za UV zračenje znamo samo po njegovim kasnijim učincima na naš organizam. $U$ ovisnosti o valnoj duljini te trajanju i intenzitetu izloženosti, ti učinci mogu biti protektivni ili rizični za zdravlje ljudi. UV zračenje potrebno je za stvaranje vitamina D koji je neophodan za uredan metabolizam kostiju kod većine kopnenih kralježnjaka, uključujući i ljude (Wacker i Holick, 2013.). Ovo zračenje koristi se i kao terapijska mjera u dermatologiji, na primjer u liječenju psorijaze i atopijskog dermatitisa. Uz prekomjerno izlaganje, štetni učinci UV zračenja su vidljivi na koži i očima u vidu tamnjenja kože, sunčanih pjega i opeklina od sunca, brzog starenja kože, pojave raka kože i oštećenja vida. UVA zrake prodiru u dublje slojeve kože i potkožno tkivo, pa su odgovorne za starenje kože (eng. aging), dok UVB zrake prodiru samo u epidermis i odgovorne su za nastanak opeklina kože (eng. burning); (Lucas i sur., 2006.).

Globalni sunčev UV indeks je razvijen kao lako razumljiva mjera biološki aktivnog UV zračenja kako bi se potakla svijest javnosti o izlaganju UV zračenju i promovirala zaštita od sunca. Vremenske prognoze u mnogim zemljama uključuju prognozu sunčevog UV indeksa. Sunčev UV indeks se pri tome definira kao vremenski ponderirano srednje efektivno UV zračenje u $\mathrm{W} / \mathrm{m}^{2}$ pomnoženo sa 40 . UV indeks je linearna 
veličina, s višim vrijednostima koje predstavljaju veći rizik od opeklina, a koji je u korelaciji s drugim zdravstvenim rizicima zbog UV izloženosti. Indeks 0 odgovara nultom UV zračenju, kao što je slučaj noću. Indeks od 10 odgovara otprilike podnevnom ljetnom suncu za vrijeme čistog neba (National Oceanic and Atmospheric Administration).

\section{Mehanizam karcinogeneze}

Apsorbirane UV zrake uzrokuju niz fotokemijskih reakcija u koži i potkožnom tkivu, među kojima su biološki najvažnije one koje uzrokuju oštećenja velikih molekula: bjelančevina i nukleinskih kiselina. UV zračenje izaziva različita oštećenja deoksiribonukleinske kiseline (DNK) od kojih je biološki najvažnije stvaranje dimera pirimidinskih baza. Naime, kada se fotoni UV zraka apsorbiraju u molekulu DNK, oni tamo povećavaju energiju elektrona u bazama i dovode do premještanja dvostrukih sveza. Tako nastaju sveze koje tvore ciklobutanski prsten između dvije susjedne baze, najčešće dva timina na istom lancu DNK. Nastankom kovalentnih dimera timina i drugih pirimidina pokreću se procesi popravka DNK. Brojna oštećenja koja nastaju na molekuli DNK izmijenila bi značenje genske poruke i bila bi nespojiva sa životom kad se ne bi mogla djelotvorno popraviti. Oštećenja DNK popravljaju brojni mehanizmi koje se smatraju osnovnim homeostatskim mehanizmima. Poremećaji popravka DNK uzrokuju nestabilnost genoma i povećan broj mutacija, što povećava izglede za zloćudnu preobrazbu stanica i pojavu zloćudnih bolesti. Sunčevo UV zračenje je prema IARC standardima (eng. IARC- International Agency for Research on Cancer) karcinogen I. skupine kao uzrok pojave kožnih malignoma (Gamulin, 2002., World Health Organization, 1992.).

\section{PROFESIONALNI KARCINOMI KOŽE}

\section{Prekanceroze i karcinomi kože}

Prekanceroze su stadiji nekog patološkog procesa kod kojih postoji povećan rizik razvoja malignog tumora, najčešće karcinoma. Prekanceroze kože kod kojih postoji veliki rizik za malignu alteraciju su keratosis actinica, cornu cutaneum, leucoplakia, rentgenske, arsenske i katranske keratoze. Ako dođe do maligne alteracije, ove prekanceroze prelaze u planocelularni karcinom. Keratosis actinica (keratosis solaris) je najčešća od prekanceroza i lokalizirana je većinom na dijelovima kože izloženim suncu. Uglavnom se pojavljuje kod osoba svijetle puti i kod onih koji su dugo izloženi sunčevom svijetlu. Nešto se češće može vidjeti kod muškaraca. Najčešće lokalizacije su dorzumi šaka, obrazi, čelo, temporalne regije, nos i ušne školjke, te donja usnica (cheilitis actinica). Žućkaste je boje, veličine do dva centimetra, blago uzdignuta $i$ čvrsto vezana za podlogu. Može ih biti i u većem broju (Basta Juzbašić, 2014.).

Karcinomi kože javljaju se u obliku bazeocelularnog ili planocelularnog karcinoma, odnosno Bowenove bolesti ili intraepidermalnog planocelularnog karcinoma in situ. Bazeocelularni karcinom je površna papula ili čvor sporog rasta, koja potječe od bazalnih stanica epidermisa. Kliničko očitovanje i biološko ponašanje bazeocelularnih karcinoma je raznoliko. Često dolazi do recidivirajućeg stvaranja kruste ili krvarenja, a promjena nastavlja s rastom. Karcinomi često naizmjence stvaraju kruste i zacjeljuju, što može neopravdano smanjiti bolesnikovu i liječnikovu zabrinutost oko važnosti promjene. Bazeocelularni karcinomi rijetko metastaziraju, ali mogu prodrijeti i uništiti okolna zdrava tkiva. U rijetkim slučajevima mogu prerasti u ulcus rodens, najopasniji oblik bazeocelularnog karcinoma s metastatskim potencijalom. Karcinom pločastih stanica ili planocelularni karcinom je zloćudni tumor epidermalnih keratinocita koji prodire u dermis, a obično nastaje na dijelovima kože izloženim suncu. Lokalno razaranje može biti opsežno, a kod uznapredovalih stadija može doći do metastaziranja. Klinička slika jako je raznolika, no sumnjiva je svaka promjena na koži izloženoj suncu koja ne zacjeljuje. Općenito je prognoza kod malih i rano odstranjenih promjena odlična (Basta Juzbašić, 2014.).

Rak kože je najčešća i po incidenciji i prevalenciji najbrže rastuća maligna bolest, osobito u bijeloj rasi diljem svijeta. Karcinom bazalnih stanica je najčešći oblik raka kože. Ova vrsta zloćudnog tumora predstavlja oko $75 \%$ svih oblika raka kože kada su u pitanju pripadnici bijele rase. Karcinom pločastih stanica, drugi najčešći 
rak kože, može se razviti u normalnom tkivu, u prethodnoj aktiničkoj keratozi, području leukoplakije ili ožiljku od opekline. U protekla dva desetljeća, u većini država članica Europske unije, stope incidencije raka kože su se udvostručile i premašile stope svih karcinoma u bijelaca (John i sur., 2016.).

\section{Individualni rizični čimbenici}

Postoje prirođena stanja koja povećavaju rizik za obolijevanje od karcinoma kože. Tu prije svega valja spomenuti albinizam i vitiligo. Okulokutani albinizam je nasljedni poremećaj stvaranja melanina koji uzrokuje difuznu hipopigmentaciju kože, kose i očiju, a najčešće je posljedica nepostojanja ili smanjenja aktivnosti tirozinaze, enzima koji katalizira nekoliko koraka u sintezi melanina. Nedostatak melanina, a stoga i pigmenta, može biti potpun ili djelomičan, no zahvaća sve dijelove kože i prezentira se s mliječno bijelom kosom i kožom, te plavo-sivim očima. Bolesnici su u velikoj opasnosti od opeklina od sunca i raka kože. Vitiligo je gubitak kožnih melanocita koji uzrokuje stvaranje različito velikih područja depigmentacije kože. Uzrok vitiliga nije poznat, no moguće je da se radi o autoimunoj promjeni, jer i do trećina bolesnika pokazuje znakove druge autoimune bolesti. Najjača povezanost uočena je s hipertireozom (Gravesova bolest) i hipotireozom (Hashimotov tiroiditis). Sva depigmentirana područja su sklona teškim opeklinama od sunca (Spencer, 2010.).

Tablica 1 prikazuje Fitzpatrickovu klasifikaciju tipova kože (preuzeto s: http://www.poliklinika-mester.hr/fitzpatrick-klasifikacija-tipovikoze/). Podjela se zasniva na odgovoru kože na prvo izlaganje podnevnom suncu tijekom ljeta u trajanju od 30 minuta. Tablica 1 prikazuje koji tip kože je najosjetljiviji prema djelovanju UV zračenja i za koji tip je najveća vjerojatnost pojavljivanja opeklina povezanih s izlaganjem sunčevom UV zračenju (D'Orazio i sur., 2013.).

\section{Rizični radni uvjeti}

Prema CAREX bazi (CARcinogen database) podataka Europske unije, više od 9 milijuna radnika diljem EU-a su izloženi UV zračenju u više od $75 \%$ njihovih dnevnih radnih sati John i sur.,
2016.). Najčešće se radi o radnicima u poljoprivredi i šumarstvu, ribolovu i pomorstvu, radnicima na izgradnji i održavanju cesta, te drugim građevinskim radnicima koji svoje radne zadatke pretežito obavljaju na otvorenom. Drugi primjeri profesionalne izloženosti su vozači poljoprivrednih ili građevinskih strojeva koji rade uz otvoren prozor.

\section{Tablica 1. Fitzpatrickova klasifikacija tipova kože}

Table 1. Fitzpatrick's skin types classification

\begin{tabular}{|c|c|c|c|c|c|}
\hline$\underset{\text { kože }}{\text { Tip }}$ & $\begin{array}{l}\text { Boja } \\
\text { kože }\end{array}$ & $\begin{array}{l}\text { Boja } \\
\text { kose }\end{array}$ & $\begin{array}{l}\text { Boja } \\
\text { očiju }\end{array}$ & $\begin{array}{l}\text { Karak- } \\
\text { teristike } \\
\text { kože }\end{array}$ & $\begin{array}{c}\text { Etnička } \\
\text { pripad- } \\
\text { nost }\end{array}$ \\
\hline I & $\begin{array}{c}\text { Vrlo } \\
\text { svijetla }\end{array}$ & Plava & $\begin{array}{l}\text { Plava/ } \\
\text { zelena }\end{array}$ & $\begin{array}{c}\text { Nikad ne } \\
\text { tamni, } \\
\text { uvijek } \\
\text { izgori }\end{array}$ & Bijelci \\
\hline II & Svijetla & $\begin{array}{c}\text { Svijetlo } \\
\text { smeđa/ } \\
\text { keste- } \\
\text { njasta }\end{array}$ & $\begin{array}{l}\text { Zelena/ } \\
\text { svijetlo } \\
\text { smeđa }\end{array}$ & $\begin{array}{l}\text { Ponekad } \\
\text { potamni, } \\
\text { ali obič- } \\
\text { no izgori }\end{array}$ & Bijelci \\
\hline III & $\begin{array}{c}\text { Svijetlo } \\
\text { masli- } \\
\text { nasta }\end{array}$ & $\begin{array}{l}\text { Keste- } \\
\text { njasta }\end{array}$ & $\begin{array}{l}\text { Svijetlo } \\
\text { smeđa }\end{array}$ & $\begin{array}{c}\text { Obično } \\
\text { potamni, } \\
\text { nekada } \\
\text { izgori }\end{array}$ & Bijelci \\
\hline IV & $\begin{array}{c}\text { Masli- } \\
\text { nasta }\end{array}$ & Tamna & Tamna & $\begin{array}{l}\text { Uvijek } \\
\text { tamni, ni- } \\
\text { kada ne } \\
\text { izgori }\end{array}$ & $\begin{array}{l}\text { Azijati, } \\
\text { Indijci, } \\
\text { Bijelci }\end{array}$ \\
\hline V & Smeđa & $\begin{array}{c}\text { Smeđa/ } \\
\text { crna }\end{array}$ & $\begin{array}{c}\text { Smeđa/ } \\
\text { crna }\end{array}$ & $\begin{array}{l}\text { Nikada } \\
\text { ne izgori }\end{array}$ & $\begin{array}{l}\text { Kreoli, } \\
\text { Mulati }\end{array}$ \\
\hline VI & $\begin{array}{l}\text { Tamno } \\
\text { smeđa }\end{array}$ & Crna & Crna & $\begin{array}{c}\text { Nikada } \\
\text { ne izgori }\end{array}$ & $\begin{array}{c}\text { Afri- } \\
\text { kanci, } \\
\text { tamno- } \\
\text { puti }\end{array}$ \\
\hline
\end{tabular}

Zahvaljujući brojnim recentnim epidemiološkim istraživanjima, nema sumnje da radnici na otvorenom nose znatno povećani rizik obolijevanja od svih tipova karcinoma kože (Trakatelli $i$ sur., 2016.). Studije pokazuju da je rizik pojave aktiničke keratoze kod radnika na otvorenom četiri puta veći od osoba koje slobodno vrijeme provode na otvorenom (Traianou i sur., 2012.). Aktinička keratoza predstavlja prvi ozbiljan znak sunčevog UV oštećenja na koži i vrlo je indikativna kao rizik za razvoj oba karcinoma kože, planocelularnog i bazeocelularnog (Salasche, 2000.). Rezultati rumunjske studije ukazuju da se u bolesnika s karcinomom bazalnih stanica koji su profesionalno izloženi UV zračenju 
češće razvijaju lezije na licu te da su te lezije patohistološki agresivnije u odnosu na bolesnike koji profesionalno nisu izloženi UV zračenju (Salavastru i sur., 2016.). Poljski poljoprivrednici pokazali su se skupinom s visokim rizikom obolijevanja od bazeoceularnog karcinoma kože, s time da su obolijevali u ranijoj dobi i imali češće recidive $u$ odnosu na bolesnike drugih zanimanja s bazeocelularnim karcinomom (Szewczyk $i$ sur., 2016.).

\section{Dozimetrija ultraljubičastog zračenja}

Okolišno UV zračenje može biti mjereno čistim fizikalnim jedinicama ili procijenjeno koristeći funkciju eritemalnog (lat. eritem - crvenilo kože) odgovora ljudske kože kako bi dobili biološki učinkovito UV zračenje, izraženo kao minimalna eritemalna doza (MED) ili standardna eritemalna doza (SED) u J/m². MED se ponekad koristi u populacijama s različitim tipovima kože, što znači da se doza UV zračenja potrebna da izazove minimalni eritemalni odgovor razlikuje kod pojedinih tipova kože (Tablica 2); (Makgabutlane i Wright, 2015.). Prema tome, MED UV zračenja mora se definirati zasebno za pojedini tip kože. SED je razvijena kao eritemalno procijenjena mjera izlaganja UV zračenju ekvivalentnom 100 $\mathrm{J} / \mathrm{m}^{2}$. SED je neovisna o tipu kože i specifična izloženost izražena u SED koja će izazvati eritem kod osoba svijetle puti, neće izazvati eritem kod osoba tamne puti (Diffey, 2002.).

Tablica 2. Doza UV zračenja izražena u SED potrebna da izazove opekline kod različitih tipova kože

Table 2. Dose of UV radiation expressed in SED (standard erythemal dose) sufficient to cause burns in different skin types

\begin{tabular}{|c|c||}
\hline Tip kože po Fitzpatricku & $\begin{array}{c}\text { Doza UV zračenja potreb- } \\
\text { na da izazove opekline } \\
\text { (SED) }\end{array}$ \\
\hline 1 & $2-3$ \\
\hline 2 & $2,5-3$ \\
\hline 3 & $3-5$ \\
\hline 4 & $4,5-6$ \\
\hline 5 & $6-20$ \\
\hline 6 & $6-20$ \\
\hline
\end{tabular}

Osobni UV dozimetri razvijeni su kako bi podržali istraživanja povezana s izlaganjem UV zračenju u odnosu na ljudsko zdravlje. Elektronički dozimetri zamjenjuju kemijski (polisulfonski) film, te su optimalno sredstvo za mjerenje osobne izloženosti UV zračenju. Do primjene osobne dozimetrije UV zračenja nisu bile dostupne informacije u kojoj su mjeri određena zanimanja povezana s izloženošću sunčevom UV zračenju. Uvid u prve podatke osobne dozimetrije UV zračenja radnika na otvorenom dobiven je istraživanjem Njemačkog socijalnog osiguranja od nesretnog slučaja (Deutsche Gesetzliche Unfallversicherung). Zadnjih godina provode se opsežna istraživanja osobne profesionalne izloženosti radnika UV zračenju, kako u Njemačkoj, tako i u drugim zemljama EU-a. Hrvatska se u ovo istraživanje uključila 2017. godine. U sklopu istraživanja osmišljen je komplet za osobnu dozimetriju s elektroničkim dozimetrom i tabletom kao glavnim dijelovima. Dozimetar radnici pričvrste manžetom na nadlakticu tijekom rada, a petkom nakon radne smjene podatke iz dozimetra prenose u centar istraživanja putem tableta. $U$ tabletu vode dnevni i tjedni dnevnik izloženosti. Na slici 1 (fotografija je vlasništvo autora) prikazan je hrvatski građevinski radnik koji provodi osobnu dozimetriju tijekom rada.

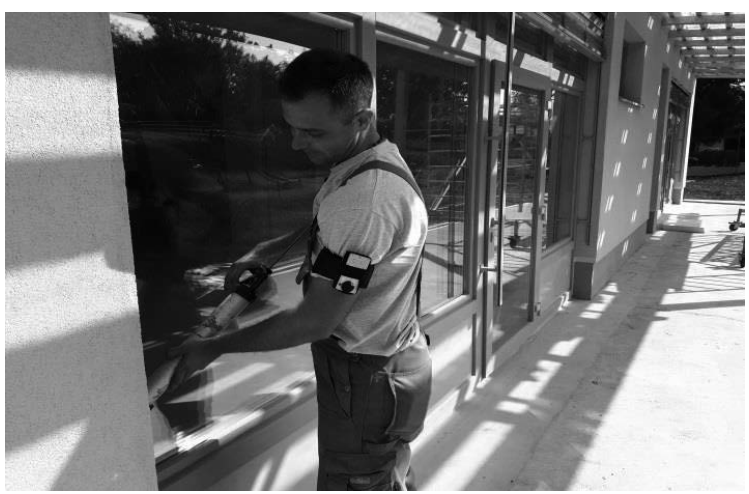

Slika 1. Građevinski radnik s osobnim dozimetrom UV zračenja na nadlaktici

Figure 1. Construction worker wearing a personal UV radiation dose meter on the upper arm

Do sada su objavljeni podaci o izloženosti radnika na otvorenom u Njemačkoj (slika 2); (preuzeto s:http://www.dguv.de/en/mediencenter/pm/presse_detail_en_131586.jsp). Podaci 
potvrđuju da godišnja izloženost UV zračenju radnika na otvorenom višestruko premašuje procijenjenu prosječnu godišnju neprofesionalnu izloženost (130 SED), te da se doza zračenja primljena u ljetnim mjesecima razlikuje s obzirom na zanimanje, tj. radno mjesto. Najveću dozu primili su radnici na izgradnji kanalizacijskog sustava, radnici u kamenolomima i radnici na izgradnji krovova i fasada (Deutsche Gesetzliche Unfallversicherung).

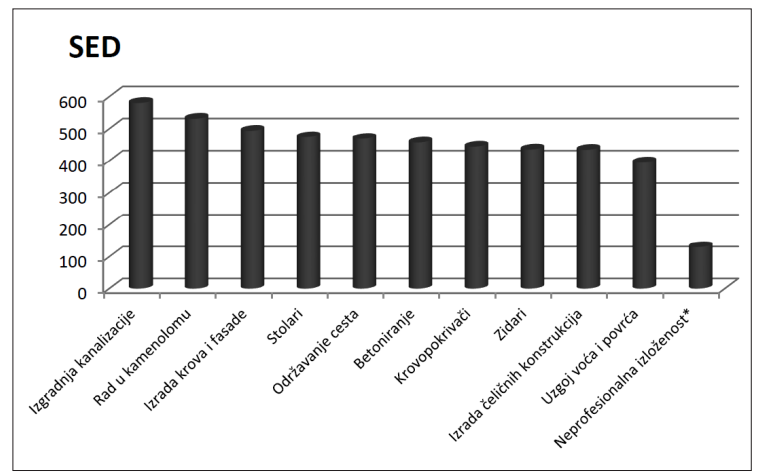

*prosječna neprofesionalna godišnja izloženost UV zračenju procjenjuje se na 130 SED

\section{Slika 2. Procijenjene ukupne godišnje izloženosti UV zračenju za radnike na otvorenom u Njemačkoj izražene u SED jedinicama}

Figure 2. Estimated total annual exposure to

UV radiation for outdoor workers in Germany expressed in SED (standard erythemal dose) units

Ako je profesionalno dobivena doza UV zračenja kod radnika na otvorenom veća za $40 \%$ od procijenjene ukupne cjeloživotne doze kod prosječne populacije (130 SED godišnje), primljeno profesionalno UV zračenje treba smatrati relevantnim, jer se rizik od tumora kože (aktinička keratoza, karcinom pločastih stanica) tada podvostručuje (Wittlich $i$ sur., 2016.). Pri tome se rizik povezan s UV izloženošću na putu na radno mjesto ne smatra relevantnim prilikom procjene profesionalne izloženosti. Na osnovi algoritma koji je osmislio Wittlich sa suradnicima (2016.), podaci iz Tablice 3 mogu biti od pomoći za grubu orijentaciju pri procjeni profesionalne izloženosti UV zračenju (Wittlich i sur., 2016.).
Tablica 3. Procjena primjerenosti prijavljivanja profesionalne bolesti kod radnika s karcinomom kože

Table 3. Estimated appropriateness of reporting occupational disease in workers with skin cancer

\begin{tabular}{||l|l|l|l|l|l||}
\hline $\begin{array}{l}\text { Dob kada se pojavio } \\
\text { karcinom kože }\end{array}$ & $\mathbf{4 0}$ & $\mathbf{5 0}$ & $\mathbf{6 0}$ & $\mathbf{7 0}$ & $\mathbf{8 0}$ \\
\hline $\begin{array}{l}\text { Minimalan broj godina } \\
\text { provedenih na radu na } \\
\text { otvorenom kao zahtjev } \\
\text { za prijavu profesionalne } \\
\text { bolesti }\end{array}$ & 12 & 15 & 18 & 21 & 24 \\
\hline
\end{tabular}

\section{Prijava karcinoma kože kao profesionalnih bolesti}

Prema Zakonu o listi profesionalnih bolesti i njegovim izmjenama i dopunama, profesionalni rak kože bio bi rak za koji se dokaže da je posljedica djelovanja štetnosti (npr. UV zračenje, RTG zračenje, katranske keratoze koje prelaze u planocelularni karcinom) u procesu rada i/ili radnom okolišu, odnosno rak za kojeg je poznato da može biti posljedica djelovanja štetnosti koje su u svezi s procesom rada i/ili radnim okolišem, a intenzitet štetnosti i duljina trajanja izloženosti toj štetnosti je na razini za koju je poznato da uzrokuje oštećenje zdravlja. Postoje čvrsti znanstveni dokazi da prirodno UV zračenje uzrokuje malignome kože i da su pojedine grupe radnika ovisno o njihovom zanimanju značajno izloženije riziku od opće populacije. To se odnosi na mulitple aktiničke keratoze, bazeocelularni i planocelularni karcinom kože. Aktinična keratoza se prema znanstvenom stavu smatra multiplom ako dolazi kao više od 5 pojedinačnih promjena godišnje ili konfluira u jednu leziju veću od 4 cm u promjeru (Diepgen i sur., 2014., Bauer $i$ sur., 2011.).

U pojedinim zemljama EU-a (na primjer u Njemačkoj) postoje kriteriji koji moraju biti ispunjeni za izvještavanje i priznavanje karcinoma kože kao profesionalne bolesti, prvenstveno procjena profesionalne izloženosti. Karcinomi kože ili multipla aktinična keratoza mogu biti prepoznati kao profesionalne bolesti ako je: 1) histološki potvrđena dijagnoza planocelularnog 
ili bazeocelularnog karcinoma kože ili multiple aktiničke keratoze; 2) promjene su izražene na profesionalno izloženim dijelovima kože; 3) povijest bolesti otkriva intenzivnu profesionalnu izloženost UV zračenju. Točna dijagnoza i lokalizacija moraju biti navedene u vrijeme prijave. U slučaju karcinoma treba biti dostupan histološki nalaz, dok za multiplu aktiničku keratozu u prijavi treba biti naznačen broj (minimalno šest) i njihova lokalizacija. U slučaju konfluentne kanceroze mora biti poznato zahvaćeno područje $\left(>4 \mathrm{~cm}^{2}\right)$ i njegova lokalizacija. Fotodokumentacija također može pomoći kako bi se dokazala dijagnoza. Procjena profesionalne izloženosti UV zračenju pri prijavi profesionalne bolesti prikazana je u Tablici 3 . Na primjer, prijava profesionalne bolesti smatra se opravdanom ako se karcinom kože pojavi na dijelovima kože izloženih suncu u radnika dobi 50 godina koji je najmanje 15 godina radio poslove na otvorenom. Shodno navedenom, radnici s karcinomima kože u Njemačkoj putem osiguranja od ozljeda na radu/profesionalnih bolesti zadnjih nekoliko godina stječu prava s osnove profesionalne bolesti (Diepgen i sur., 2014).

Pitanje harmonizacije kriterija za priznavanje profesionalnih karcinoma kože uzrokovanih sunčevim UV zračenjem na razini EU-a razmatrano je u sklopu upravo dovršenog COST projekta TD1206 StanDerm u kojem su sudjelovali i stručnjaci iz Hrvatske. Jedan od rezultata ovog projekta je i harmonizirani obrazac za prijavu karcinoma kože kao profesionalnih bolesti koji je preveden na hrvatski jezik i dostupan na internetskoj stranici projekta StanDerm (COST Action TD1206, 2017.).

U Hrvatskoj važeći Zakon o listi profesionalnih bolesti i njegovim izmjenama i dopunama daje mogućnost prijave profesionalnih karcino- ma kože uzrokovanih sunčevim UV zračenjem pod točkom 39. „Bolesti uzrokovane neionizirajućim zračenjima", a s obzirom na provedena istraživanja i procese standardizacije prijave profesionalnih karcinoma kože na razini EU-a, stekli su se uvjeti za donošenjem nacionalnih algoritama za prijavu profesionalnih karcinoma kože (Ulrich i sur., 2016.).

\section{Prevencija profesionalnih karcinoma kože}

U sklopu spomenutog COST projekta TD1206, objavljeno je zajedničko stajalište stručnjaka uključenih u projekt o minimalnim standardima u prevenciji profesionalnih karcinoma kože u EU (Alfonso i sur., 2017.). Naime, ranije je od nekih autora ukazano da su zdravstvena pismenost i sklonost prevenciji štetnih učinaka UV zračenja vrlo ograničeni kod radnika na otvorenom (Trakatelli i sur., 2016.), a upravo prevencija je najznačajnija za smanjenje rizika od karcinoma kože kod radnika na otvorenom. Kako bi se spriječili tumori kože uzrokovani profesionalnom UV izloženosti, obvezno je značajno smanjenje profesionalno stečenih UV doza kod radnika na otvorenom. Mjerodavni čimbenici koji utječu na izloženost suncu kod radnika na otvorenom su tehničke i organizacijske preventivne mjere, količina izloženosti UV zračenju, specifični zadaci koji se obavljaju na suncu, kao i navike UV zaštite od samih radnika (Bauer i sur., 2015., International Commission on Non-ionizing Radiation Protection, 2004.). U Tablici 4 prikazane su preporučene preventivne strategije za smanjenje pojave profesionalnog karcinoma kože uzrokovanog sunčevim UV zračenjem (Alfonso i sur., 2017.). Minimalnim standardima prevencije na razini EU-a smatraju se primjene opisanih mjera osobne zaštite i programa edukacije, na kojima bi trebalo inzistirati u svim državama EU-a (Alfonso i sur., 2017.). 
Tablica 4. Preventivne strategije kod profesionalnih karcinoma kože uzrokovanih sunčevim UV zračenjem

Table 4. Prevention strategies in occupational skin cancers caused by solar UV radiation

\begin{tabular}{||l|l||}
\hline \multicolumn{1}{|c|}{ Preventivne strategije } & \multicolumn{1}{c|}{ Rak kože povezan sa zanimanjem } \\
\hline $\begin{array}{l}\text { Tehničke/organizacijske } \\
\text { mjere }\end{array}$ & $\begin{array}{l}\text { Natkrivanje trajnih radnih mjesta (npr. kiosci za naplatu na parkiralištima), upotreba mobilnih } \\
\text { sunčanih panela ili sunčanih sjenila, upotreba UV apsorbirajućeg prozorskog stakla na vozilima, } \\
\text { pružanje sjenovitih mjesta za odmor ili odmor u zatvorenim prostorijama, izbjegavanje UV izlo- } \\
\text { ženosti tijekom podnevnih sati ranijim početkom rada i prolongiranom pauzom za vrijeme ručka. }\end{array}$ \\
\hline Osobna zaštita* & $\begin{array}{l}\text { Sunčane naočale za rad moraju ispunjavati zahtjeve norme DIN EN 172, odgovarajuća odjeća } \\
\text { su hlače i majice s dugim rukavima od laganih materijala (pamučna ili sintetička vlakna) sa za- } \\
\text { štitnim faktorom } 50 \text { barem na području ramena, odgovarajuća pokrivala za glavu su kacige ili } \\
\text { šeširi širokih oboda sa dodatnim šiltom i pokrivalom za vrat (standardne sigurnosne kacige ne } \\
\text { pružaju dostatnu zaštitu od sunca za lice, uši i vrat). Kreme za sunčanje moraju biti nanesene na } \\
\text { svim nepokrivenim područjima kože i moraju sadržavati vrlo visoke, širokopojasne, fotostabilne } \\
\text { filtre za UVB i UVA (SPF 50+, UVA-PF> 1/3 SPF). Moraju biti lako primjenjive i otporne na znoj } \\
\text { i konačno, ne smiju izazivati iritaciju kože i očiju. }\end{array}$ \\
\hline Programi edukacije* & $\begin{array}{l}\text { Informacije o zdravlju i sigurnosti na radu trebaju bili implementirane u kurikul srednjih strukov- } \\
\text { nih škola i redovito pružane na radnim mjestima. U sekundarnoj i tercijarnoj prevenciji, tj. kada } \\
\text { je bolest već prisutna, korisne su radionice o specifičnoj zaštiti kože na radu kao i induvidualno } \\
\text { savjetovanje o promjenama navika ponašanja. }\end{array}$ \\
\hline Pristup stručnjacima & $\begin{array}{l}\text { Dermatolozi, specijalisti medicine rada, ili drugi specijalisti koji su podučeni u području profe- } \\
\text { sionalnih kožnih bolesti moraju biti dostupni za preglede prije zapošljavanja i prije školovanja, } \\
\text { za savjetovanje visokorizičnih skupina kao i za zaposlenike za rano postavljanje dijagnoze i } \\
\text { liječenje. }\end{array}$ \\
\hline
\end{tabular}

* Minimalni standardi prevencije

\section{ZAKLJUČCI}

1. Sunčevo UV zračenje je dokazani humani karcinogen koji uzrokuje pojavu malignoma kože. Rak kože je najčešća i po incidenciji i prevalenciji najbrže rastuća maligna bolest, osobito u bijeloj rasi diIjem svijeta.

2. Izlaganje sunčevom UV zračenju tijekom rada na otvorenom 4-5 puta povećava primljenu prosječnu godišnju dozu UV zračenja u odnosu na osobe koje ne rade na suncu, što kod radnika koji rade na otvorenom značajno povećava rizik pojave aktiničke keratoze, bazeocelularnog i planocelularnog karcinoma kože. Smatra se da se rizik za pojavu ovih poremećaja udvostručuje ako je prosječna godišnja doza UV zračenja za osobe koje ne rade izložene suncu premašena za $40 \%$. U zemljama EU-a, uključujući i Hrvatsku, u tijeku je uvođenje osobne dozimetrije UV zračenja za radnike koji rade na otvorenom.
3. Karcinomi kože ili multipla aktinična keratoza mogu biti prepoznati kao profesionalne bolesti ako su zadovoljeni sljedeći kriteriji: 1) histološki potvrđena dijagnoza planocelularnog ili bazeocelularnog karcinoma kože ili multiple aktiničke keratoze (minimalno 6 promjena); 2) promjene su izražene na profesionalno izloženim dijelovima kože; 3) povijest bolesti otkriva dostatnu profesionalnu izloženost UV zračenju.

4. U Hrvatskoj, važeći Zakon o listi profesionalnih bolesti daje mogućnost prijave profesionalnih karcinoma kože uzrokovanih sunčevim UV zračenjem pod točkom 39. „Bolesti uzrokovane neionizirajućim zračenjima", a s obzirom na provedena istraživanja i procese standardizacije prijave profesionalnih karcinoma kože na razini EU-a, stekli su se uvjeti za donošenjem nacionalnih algoritama za prijavu profesionalnih karcinoma kože.

5. Kako bi se spriječili tumori kože uzrokovani profesionalnom UV izloženosti, 
obvezno je značajno smanjenje profesionalno stečenih UV doza kod radnika na otvorenom provođenjem preventivnih mjera. Minimalnim standardima prevencije na razini EU-a smatraju se primjene mjera osobne zaštite (naočale, pokrivala za glavu, odjeća, kreme sa zaštitnim faktorom) i programa edukacije o zdravlju i sigurnosti na radu implementiranih u kurikule srednjih strukovnih škola i redovito pružane na radnim mjestima.

\section{LITERATURA}

Alfonso, J.H., Bauer, A., Bensefa-Colas, L., et al.: Minimum standards on prevention, diagnosis and treatmentof occupational and work-related skin diseases in Europe -position paper of the COST Action StanDerm (TD 1206). JEADV, 31, 2017., Suppl. 4, str. 31-43.

Basta-Juzbašić, A. i sur.: Dermatovenerologija. Medicinska naklada, Zagreb, 2014.

Bauer, A., Beissert, S., Knuschke, P.: [Prevention of occupational solar UV radiation-induced epithelial skin cancer] (članak na njemačkom jeziku). Hautarzt Für Dermatol Venerol Verwandte Geb, 66, 2015., str. 173-178.

Bauer, A., Diepgen, T.L., Schmitt, J.: Is occupational solar ultraviolet irradiation a relevant risk factor for basal cell carcinoma? A systematic review and meta-analysis of the epidemiological literature. Br J Dermatol, 165, 2011., str. 612-625.

COST Action TD1206. Development and Implementation of European Standards on Prevention of Occupational Skin Diseases, StanDerm, 2013.-2017. Dostupno na: http://www.standerm. eu, Pristupljeno: 26.2.2018.

Deutsche Gesetzliche Unfallversicherung (DGUV): A big dose of sunshine: during work outdoors, the skin receives a significant amount of UV radiation. Dostupno na: http://www.dguv.de/ en/mediencenter/pm/presse_detail_en_131586. jsp, Pristupljeno: 26.2.2018.

Diepgen, T.L., Brandenburg, S., Aberer, W., et al.: Skin cancer induced by natural UV-radiation as an occupational disease - Requirements for its notification and recognition. JDDG: Journal der Deutschen Dermatologischen Gesellschaft, 12, 2014., str. 1102-1106.
Diffey, B.L.: Sources and measurement of ultraviolet radiation. Methods, 28, 2002., 1, str. 4-13.

D'Orazio, J., Jarrett, S., Amaro-Ortiz, A., Scott, T.: UV Radiation and the Skin. Int I Mol Sci, 14, 2013., 6, str.12222-12248.

Gamulin, S.: Poremećaji građe i funkcije DNA: Oštećenja DNA zračenjem. U: Gamulin, S., Marušić, M., Kovač, Z. i sur.: Patofiziologija, V. obnovljeno i izmijenjeno izdanje. Medicinska naklada, Zagreb, 2002., str. 47.

International Commission on Non-lonizing Radiation Protection. Guidelines on limits of exposure to ultraviolet radiation of wavelengths between $180 \mathrm{~nm}$ and $400 \mathrm{~nm}$ (incoherent optical radiation). Health Phy, 87, 2004., str. 171-186.

John, S.M., Trakatelli, M., Ulrich, C.: Non-melanoma skin cancer by solar UV: the neglected occupational threat. JEADV, 30, 2016., Suppl.3, str. 3-4.

Lucas, R., McMichael, T., Smith, W., Armstrong, B.: Solar Ultraviolet Radiation. Global burden of disease from solar ultraviolet radiation. Geneva: World Health Organization, 2006. Dostupno na: http://www.who.int/uv/health/solaruvradfull_180706.pdf, Pristupljeno: 26.2.2018.

Lynch, D.K., Livingston, W.C.: Limits of the eye's overall range of sensitivity extends from about 310 to 1050 nanometers. U: Livngston W.C. (ur.): Color and Light in Nature, 2nd ed., Cambridge, UK: Cambridge University Press, 2001., str. 231. Dostupno na: https://books.google.hr/books?id=4Abp5FdhskAC\&pg=PA231\&r edir_esc $=\mathrm{y} \# \mathrm{v}=$ onepage $\& \mathrm{q} \& \mathrm{f}=\mathrm{false}$ Pristupljeno: 26.2.2018.

Makgabutlane, M., Wright, C.Y.: Real-time measurement of outdoor worker's exposure to solar ultraviolet radiation in Pretoria, South Africa. South African Journal of Science, 111, 2015., 5/6, str. 1-7.

NASA, Mission Science: Ultraviolet waves. Dostupno na: https://web.archive.org/ web/20110127004149/http:/missionscience. nasa.gov/ems/10_ultravioletwaves.html, Pristupljeno: 26.2.2018.

National Oceanic and Atmospheric Administration: UV Index Information. Dostupno na: http://www.cpc.ncep.noaa.gov/products/stratosphere/uv_index/uv_validate.shtml, Pristupljeno: 26.02.2018. 
Pravilnik o poslovima s posebnim uvjetima rada, N.N., br. 5/1984.

Salasche, S.J.: Epidemiology of actinic keratoses and squamous cell carcinoma. I Am Acad Dermatol, 42, 2000., str. 4-7.

Salavastru, C.M., Ulrich, C., Cretu, S., et al.: The experience of a tertiary referral centre in Romania on basal cell carcinomas in outdoor workers: why to assess? JAEDV, 30, 2016., Suppl. 3, str. 12-16.

Spencer, S.: Rak kože: karcinom pločastih stanica. U: Beers, Porter, Jones, Kaplan, Berkwits (ur.): MSD priručnik dijagnostike i terapije, XVIII američko izdanje, II hrvatsko izdanje. Split: Placebo doo, 2010., str. 1023-1028.

Szewczyk, M., Pazdrowski, J., Golusiński, P., Dańczak-Pazdrowska, A., Łuczewski, L., Marszałek, S., Majchrzak, E., Golusiński, W.: Basal cell carcinoma in farmers: an occupation group at high risk. Int Arch Occup Environ Health, 89, 2016., str. 497-501.

Traianou, A., Ulrich, M., Apalla, Z., et al.: Risk factors for actinic keratosis in eight European centres: a case-control study. Br J Dermatol, 2012,167, Suppl. 2, str. 36-42.

Trakatelli, M., Barkitzi, K., Apap, C. et al.: Skin cancer risk in outdoor workers: a European mul- ticenter case-control study. JEADV, 30, 2016., Suppl. 3, str. 5-11.

Ulrich, C., Salavastru, C., Agner, T., et al.: The European Status Quo in legal recognition and patientcare services of occupational skin cancer. JE$A D V$, 30, 2016., Suppl. 3, str. 46-51.

Wacker, M., Holick, M.F.: Sunlight and vitamin D. DermatoEndocrinology, 5, 2013., 1, str. 51-108.

Wittlich, M., Westerhausen, S., Kleinespel, P., Rifer, G., Stöppelmann, W.: An approximation of occupational lifetime UVR exposure: algorithm for retrospective assessment and current measurements. JEADV, 30, 2016., Suppl. 3, str. 27-33.

World Health Organization. IARC Monographs on the Evaluation of Carcinogenic Risks to Humans. Solar and ultraviolet radiation. Volume 55, 1992. Dostupno na: http://monographs.iarc. fr/ENG/Monographs/vol55/mono55.pdf, http:// monographs.iarc.fr/ENG/Monographs/vol100D/ mono100D-6.pdf, Pristupljeno 26.2.2018.

Zakon o listi profesionalnih bolesti, N.N., br. 162/1998.

Zakon o izmjenama i dopunama Zakona o listi profesionalnih bolesti, N.N., br.107/2007.

Zavalić, M.: Profesionalni karcinomi. Sigurnost, 48, 2006., 1, str. 11-17. 


\section{SKIN CARCINOMA CAUSED BY SOLAR RADIATION AS AN OCCUPATIONAL DISEASE}

SUMMARY: The aim of this review article is to point out to the danger for workers who, by the nature of their occupation, spend most of their working hours outdoor and are exposed to sunlight that increases their risk of skin cancer.

Exposure to sunlight during outdoor work increases the average annual dose of UV radiation for 4-5 times compared to people who do not work in the sun, which in outdoor workers significantly increases the risk for the occurrence of actinic keratosis, basal-cell skin cancer and squamous-cell skin cancer. It is considered that the risk for the occurrence of these disorders is doubled if the total lifetime UV radiation dose for persons occupationally non exposed to sun (130 SED annually) is exceeded by 40\%. In the EU countries, including Croatia, the introduction of UV radiation personal dosimetry for outdoors workers is in progress.

In order to prevent skin cancer caused by occupational UV exposure, it is necessary to implement preventive measures for outdoor workers. Minimum standards for prevention at the EU level include the application of personal protection measures (sunglasses, headgear, clothing, creams with sun protective factor) and health and safety educational programs implemented in the curricula of secondary high schools, and provided to workers at risky workplaces.

Skin cancers or multiple actinic keratosis can be recognized as an occupational disease if: 1) diagnosis of squamous-cell skin cancer or basal-cell skin cancer or multiple actinic keratosis (minimum 6 changes) is histologically confirmed; 2) the changes are expressed in occupationally exposed areas of the skin; 3) the history of the disease reveals sufficient occupational exposure to $U V$ radiation.

Key words: ultraviolet radiation, carcinogens, outdoor work, personal dosimetry, prevention, personal protective equipment 